Зуза В. С., доктор сільськогосподарських наук,

Рожкков А. О., доктор сільськогосподарських наук

Харківський національний аграрний університет ім. В. В. Докучаєва

Гутянський Р. А., кандидат сільськогосподарських наук

Інститут рослинництва ім. В. Я. Юр'єва НААН

\title{
УРОЖАЙНІСТЬ СОЇ ЗАЛЕЖНО ВІД ПОПЕРЕДНИКА, МЕТЕОРОЛОГІЧНИХ УМОВ ТА ЕФЕКТИВНОСТІ ГЕРБІЦИДУ
}

\section{Рецензент - доктор сільськогосподарських наук В. П. Петренкова}

Наведені результати чотирирічних досліджень щзодо впливу попередників, зокрема пшениці озимої $i$ ячменю ярого та трунтового гербіииду Харнес на врожайність сої в роки з різним рівнем вологозабезпечення. Встановлено, щуо трунтовий гербіцид Харнес контролював загальну кількість $і$ сиру масу бур'янів за попередником пшениия озима відповідно на 92 і $93 \%$, а за попередником ячмінь ярий - на 91 і $83 \%$. Виявлено, щчо після попередника пшениця озима формувалась більша врожайність сої, ніж після попередника ячмінь ярий.

Ключові слова: соя, врожайність, попередник, метеорологічні умови, бур'яни, гербіцид Харнес.

Постановка проблеми. В сучасних умовах ринкових відносин у сільськогосподарському виробництві України відбулась помітна зміна пріоритетів з вирощування економічно вигідних культур, що призвело до розширення площ під соєю. За обсягами виробництва в нашій країні соя вийшла на перше місце в Свропі [4].

До шкідливих чинників, які стримують підвищення врожайності сої відносять бур'яни. Достовірне зниження врожайності сої (на $11 \%$ ) виявлено за наявності 5 шт./ $\mathrm{M}^{2}$ малорічних бур'янів. Зростання рівня забур'яненості до 10 15 шт./м² зменшує продуктивність сої на 26$31 \%$ [1]. Тому заходи захисту від бур'янів повинні бути спрямовані на створення більш сприятливих умов для одержання високої продуктивності сої. Важливе значення тут мають заходи 3 визначення кращих попередників та ефективності гербіцидів.

Аналіз основних досліджень і публікацій, у яких започатковано розв'язання проблеми. Вивчення впливу попередників під сою - питання далеко не нове [2, 5], проте воно зберігає свою актуальність і зараз, оскільки відбуваються зміни в кількісному і якісному складі бур'янів у посівах більшості сільськогосподарських куль- тур [3], які потребують постійного уточнення елементів технології вирощування цієї культури.

Мета досліджень - з'ясувати вплив попередників, зокрема пшениці озимої і ячменю ярого, метеорологічних умов та грунтового гербіциду Харнес на врожайність насіння сої.

Завдання досліджень: встановити кращий попередник, а також ефективність гербіциду Харнес для формування вищого рівня продуктивності сої.

Умови і методика проведення досліджень. Дослід проводили впродовж 2009-2012 рр. у лабораторії рослинництва і сортовивчення Інституту рослинництва ім. В. Я. Юр'єва НААН. Контроль (з бур'янами) - забур'янений посів, без застосування гербіциду і ручних прополювань. Контроль (без бур'янів) - систематичні ручні прополювання, без застосування гербіциду. Грунтовий гербіцид Харнес (діюча речовина - ацетохлор, 900 г/л) застосовували в досходовий період, без загортання в грунт.

Грунт дослідного поля - чорнозем типовий важкосуглинковий. Під передпосівну культивацію вносили $\mathrm{N}_{30} \mathrm{P}_{30} \mathrm{~K}_{30}$. Висівали сорт сої Романтика 3 шириною міжрядь -45 см. Розмір облікової ділянки $-36 \mathrm{~m}^{2}$, повторення триразове. Збирання врожаю проводили селекційним комбайном «Sampo-130».

Результати досліджень. У контролі (з бур'янами) по обох попередниках як за кількістю, так і за масою домінували злакові однорічні бур'яни у посівах сої, які були представлені плоскухою звичайною і мишієм сизим. На другому місці були дводольні малорічні бур'яни 3 домінуванням щириці звичайної. Коренепаросткових бур'янів, де переважав осот рожевий, було значно менше, ніж представників двох попередніх груп. Найбільша загальна кількість і сира маса бур'янів виявлена за попередником пшениця озима (табл. 1). 
СІЛЬСЬКЕ ГОСПОДАРСТВО. РОСЛИННИЦТВО

\section{1. Вилив попередника та гербіциду Харнес на забур'яненість посіву сої}

\begin{tabular}{|c|c|c|c|c|c|c|c|}
\hline \multirow{2}{*}{ Попередник } & \multirow{2}{*}{ Варіант } & \multirow{2}{*}{$\begin{array}{c}\text { Бур'янів у кінці } \\
\text { вегетації }\end{array}$} & \multicolumn{5}{|c|}{ Рік } \\
\hline & & & 2009 & 2010 & 2011 & 2012 & середнє \\
\hline \multirow{4}{*}{ Пшениця озима } & \multirow{2}{*}{$\begin{array}{c}\text { Контроль } \\
\text { (3 бур'янами) }\end{array}$} & кількість, шт./м² & 135 & 262 & 71 & 148 & 154 \\
\hline & & сира маса, г/м² & 793 & 445 & 832 & 651 & 680 \\
\hline & \multirow{2}{*}{$\begin{array}{l}\text { Харнес, } \\
2,5 \text { л/га }\end{array}$} & кількість, шт./м² & 23 & 5 & 12 & 6 & 12 \\
\hline & & сира маса, $\Gamma / \mathrm{M}^{2}$ & 39 & 11 & 94 & 50 & 49 \\
\hline \multirow{4}{*}{ Ячмінь ярий } & \multirow{2}{*}{$\begin{array}{c}\text { Контроль } \\
\text { (3 бур'янами) }\end{array}$} & кількість, шт./м² & 75 & 41 & 112 & 338 & 142 \\
\hline & & сира маса, г/м² & 372 & 138 & 803 & 932 & 561 \\
\hline & \multirow{2}{*}{$\begin{array}{l}\text { Харнес, } \\
2,5 \text { л/га }\end{array}$} & кількість, шт./м² & 7 & 1 & 24 & 17 & 12 \\
\hline & & 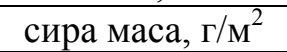 & 17 & 2 & 230 & 132 & 95 \\
\hline
\end{tabular}

Загальна загибель бур'янів у посівах сої на фоні застосування гербіциду Харнес у середньому за попередником пшениця озима і ячмінь ярий становила відповідно 92 і 91 \%. Що ж до загальної сирої маси бур'янів, то вона зменшувалася за попередником пшениця озима і ячмінь ярий відповідно на 93 і 83 \%. Ефективність цього гербіциду залежала від кількості опадів, що випали в перші дні після його внесення. Так, у 2009, 2010, 2011 і 2012 рр., коли в перші 20 діб після застосування препарату випало відповідно 35, 56, 18 і 27 мм опадів, зменшення загальної кількості бур'янів щодо попередника пшениця озима та ячмінь ярий становило 83, 98, 83 і $96 \%$ та 91, 98, 79 і $95 \%$, а їх сирої маси $95,98,89$ i $92 \%$ та $95,99,71$ i $86 \%$.

Грунтові гербіциди не діють на коренепаросткові бур'яни, що не дає нам підстав аналізувати ïx. Тому, характеризуючи ефективність грунтового гербіциду Харнес, слід розглядати його вплив лише на злакові однорічні та дводольні малорічні бур'яни. Встановлено, що у попередника пшениця озима цей препарат у середньому зменшував кількість i сиру масу злакових однорічних бур'янів відповідно на 93 і $94 \%$, а дводольних малорічних - на 94 і $96 \%$. У попередника ячмінь ярий гербіцид Харнес контролював кількість і сиру масу злакових однорічних бур'янів відповідно на 92 і 86 \%, а дводольних малорічних - на 94 i 87 \%. У посівах сої гербіцид Харнес по попереднику пшениця озима і ячмінь ярий знищував плоскуху звичайну відповідно на 94 і 93 \%, а мишій сизий - на 97 і $93 \%$. Щирицю звичайну цей гербіцид знищував у попередника пшениця озима на $98 \%$, а у попередника ячмінь ярий - на $95 \%$.

На рівень урожайності сої в окремі роки досліджень значною мірою впливав режим зволоження в критичний для формування врожайності період (від III декади червня по III декаду серпня включно). Зокрема у 2009, 2010, 2011 і 2012 pp. за кількості опадів у цей період відповідно 110 , 118, 296 і 151 мм урожайність у контролі (без бур'янів) по попереднику пшениця озима становила 1,94, 1,26, 3,02 і 1,60 т/га, а по попереднику ячмінь ярий - 2,02, 1,00, 2,60 і 1,46 т/га (табл. 2). Коефіцієнт кореляції між урожайністю сої та кількістю опадів у роки досліджень становив за попередником пшениця озима і ячмінь ярий відповідно $\mathrm{r}=0,90 \mathrm{i} r=0,75$. Зауважимо, що в $2010 \mathrm{p}$. найменша врожайність насіння сої була обумовлена відсутністю опадів у період наливу бобів і високою середньодобовою температурою повітря $\left(28,0{ }^{\circ} \mathrm{C}\right)$.

\section{2. Урожайність сої залежно від впливу попередника та дії гербіциду Харнес}

\begin{tabular}{|c|c|c|c|c|c|c|}
\hline \multirow{2}{*}{$\begin{array}{c}\text { Попередник } \\
\text { (чинник А) }\end{array}$} & \multirow{2}{*}{$\begin{array}{c}\text { Варіант захисту } \\
\text { (чинник В) }\end{array}$} & \multicolumn{4}{|c|}{ Урожайність, т/га } & \multirow{2}{*}{ Середне } \\
\hline & & 2009 p. & $2010 \mathrm{p}$. & $2011 \mathrm{p}$. & $2012 \mathrm{p}$. & \\
\hline \multirow{3}{*}{$\begin{array}{l}\text { Пшениця } \\
\text { озима }\end{array}$} & Контроль (з бур'янами) & 1,37 & 0,66 & 2,45 & 0,91 & 1,35 \\
\hline & Контроль (без бур'янів) & 1,94 & 1,26 & 3,02 & 1.60 & 1,96 \\
\hline & Харнес, 2,5 л/га & 1,95 & 1,23 & 2,83 & 1,52 & 1,88 \\
\hline \multirow{3}{*}{ Ячмінь ярий } & Контроль (з бур'янами) & 1,69 & 1,00 & 1,87 & 0,52 & 1,27 \\
\hline & Контроль (без бур'янів) & 2,02 & 1,00 & 2,60 & 1,46 & 1,77 \\
\hline & Харнес, 2,5 л/га & 1,85 & 0,91 & 2,40 & 1,39 & 1,64 \\
\hline \multicolumn{2}{|c|}{$\mathrm{HIP}_{05}$ головного ефекту чинника $\mathrm{A}$} & 0,13 & 0,16 & 0,22 & 0,23 & \\
\hline \multirow{2}{*}{\multicolumn{2}{|c|}{$\begin{array}{c}\text { НІР }_{05} \text { головного ефекту чинника В } \\
\text { HІР }_{05} \text { взаємодії АВ }\end{array}$}} & 0,16 & 0,20 & 0,27 & 0,28 & \\
\hline & & 0,22 & 0,28 & 0,39 & 0,39 & \\
\hline
\end{tabular}




\section{СІЛЬСЬКЕ ГОСПОДАРСТВО. РОСЛИННИЦТВО}

На контролі (без бур'янів) за попередником пшениця озима врожайність сої була більшою на 0,19 т/га, ніж за попередником ячмінь ярий.

Урожайність сої в роки досліджень знаходилася в прямій залежності від рівня забур'яненості попередника. Так, порівняно з попередником ячмінь ярий, в контролі (3 бур'янами) за попередником пшениця озима в 2009 і 2010 рр. більший рівень забур'яненості обумовив зменшення врожайності сої відповідно на 0,32 i 0,34 т/га, а в 2011 і 2012 pp. менший piвень забур'яненості сприяв збільшенню врожайності сої на 0,58 і 0,39 т/га. На контролі (без бур'янів) за попередником ячмінь ярий урожайність сої була меншою на 0,08 т/га, ніж по попереднику пшениця озима.

Під час використання гербіциду Харнес по попереднику пшениця озима щорічно формувалась більша урожайність сої, ніж по попереднику ячмінь ярий. Так, приріст урожайності сої від застосування гербіциду Харнес за попередником пшениця озима у 2009, 2010, 2011 і 2012 рр. був більшим на $0,10,0,32,0,33$ і 0,13 т/га, порівняно

\section{БІБЛІОГРАФІЯ}

1. Бабич А. О. Боротьба з бур'янами в посівах сої в Лісостепу України / А. О. Бабич, В. П. Борона, В. С. Задорожний // Пропозиція. - 2001. №1. - C. 54-55.

2. Бабич А. О. Проблеми білка і вирощування зернобобових на корм / А. О. Бабич. - [3-є вид., переробл. і доповн.]. - К. : Урожай, 1993. - 152 с.

3. Манько Ю. П. Багаторічний моніторинг впливу систем основного обробітку грунту в зерно-просапній сівозміні на забур'яненість ріллі / Ю. П. Манько, I. В. Литвиненко : [зб. наук. праць ІБЕКіЦБ НААН. Спец. випуск : («Бур’яни,
3 попередником ячмінь ярий. Порівняно 3 контролем (з бур'янами), приріст урожайності сої від застосування препарату Харнес по попереднику пшениця озима і ячмінь ярий становив відповідно 0,53 і 0,37 т/га.

Висновок. У посівах сої за попередником пшениця озима виявлено більшу загальну кількість і сиру масу бур'янів, ніж по попереднику ячмінь ярий. Грунтовий гербіцид Харнес контролював загальну кількість і сиру масу бур'янів у попередника пшениця озима відповідно на 92 i $93 \%$, а у попередника ячмінь ярий - на 91 i 83 \%. Ефективність цього гербіциду залежала від кількості опадів, що випали в перші дні після його внесення.

За попередником пшениця озима формувалась більша врожайність сої, ніж по попереднику ячмінь ярий. Також урожайність сої залежала від режиму зволоження в період вегетації та рівня забур'яненості на окремому варіанті. За використання гербіциду Харнес по попереднику пшениця озима щорічно формувалась більша врожайність сої, ніж за попередником ячмінь ярий.

особливості їх біології та систем контролювання у посівах сільськогосподарських культур»)]. - К. : «Колобіг» Фенікс, 2012. - С. 143-149.

4. Петриченко В. Ф. Агроекологічні аспекти адаптивної технології вирощування сої в Лісостепу західному / [В. Ф. Петриченко, А. О. Бабич, О. С. Чинчик та ін.] // Посібник українського хлібороба. - 2013. - Т.2. - С. 177-185.

5. Рослинництво з основами кормовиробництва : [навч. посібник / за ред. О. Г. Жатова]. - Суми : ВТД «Університетська книга», 2003. - 384 с. 